\title{
STUDI KUALITATIF PERSEPSI CITRA TUBUH REMAJA YANG KURUS DAN GEMUK SERTA UPAYA UNTUK MENCAPAI TUBUH IDEAL PADA SISWI SMA NEGERI 1 KOTA BOGOR
}

\author{
Pusparini $^{1}$, Refdanita ${ }^{2}$, Tonny C Maigoda ${ }^{3}$, dan Dodik Briawan ${ }^{4}$ \\ 1 Jurusan Gizi Poltekkes Bandung \\ Jl. Babakan Loa - Gunung Batu, Cimahi Utara-Kota Cimahi, Bandung \\ ${ }^{2}$ Prodi Farmasi ISTN Jakarta \\ ${ }^{3}$ Jurusan Gizi Poltekkes Bengkulu \\ ${ }^{4}$ Departemen Gizi FEMA IPB
}

\begin{abstract}
Body image distortion has been linked with mind, emotion, sensation and strongly related to size, and shape of individual performance. This research aimed to investigate the perception of body image for adolesscent in the second grade of senior high school in SMAN 1 Bogor. A qualitative design was used to conduct this research by using indepth interview with phenomenology approach. Six students, who were all women, consist of three students were overweight/obese and the other were lean. All of students were interviewed regarding their perception related three domain areas which were: body perception, perception of current body and efforts for achieving the ideal body composition shape. The findings indicated the three student who were overweigt/obese pointed out that they were happy and accepted with their performance but they were not better performing. The other of three student who were lean stated that they had many perception with their body image such as: thin, was not good looking, and unbalancing high and weight. Almost all of the students had a similar perception about their body image whether they were overweight/obese and lean. They were not unhappy with their performance, but they had the same opinion about ideal body shape.
\end{abstract}

Keywords: Body Image Perception, Ideal Body.

\section{PENDAHULUAN}

Citra tubuh merupakan persepsi, perasaan dan pikiran seseorang mengenai bentuk tubuh yang dimilikinya. Penilaian ini dibentuk berdasarkan persepsi, emosi, sensasi fisik, dan dapat berubah sesuai dengan suasana hati, pengalaman fisik yang dialami, dan pendapat orang lain yang ada di lingkungan orang tersebut.
Persepsi citra tubuh seseorang terhadap tubuh ideal, dibagi menjadi dua, yaitu persepsi tubuh ideal positif dan persepsi tubuh ideal negatif. Persepsi tubuh positif, jika hasil hasil persepsi seseorang terhadap bentuk tubuhnya sama dengan status gizi yang dimiliki, sedangkan persepsi tubuh negatif, jika hasil persepsi seseorang terhadap tubuhnya berbeda dengan status gizi 
yang dimiliki oleh orang tersebut (Cash, 2002).

Masa remaja merupakan masa transisi seseorang dari anak-anak menjadi dewasa, pada masa ini, remaja terutama remaja putri mulai sadar akan identitas diri dan lebih banyak memberikan perhatian yang besar terhadap bentuk atau citra tubuh. Adanya pergeseran citra tubuh ideal pada remaja putri saat ini memberikan penilaian menarik tidaknya seseorang diidentikkan tubuh kurus atau langsing. Hal ini mengakibatkan banyak remaja yang melakukan usaha pengaturan makanannya sehari-hari. Perilaku lah pola makan yang salah sehingga menimbulkan gangguan perilaku makan, bisa dalam bentuk Anoreksia, Bulimia Nervosa ataupun gangguan makan tidak spesifik lainnya yang berdampak negatif bagi remaja wanita.

Menurut Cash (2002) serta Zoletic dan Belko (2009) gangguan citra tubuh adalah pandangan yang berlebihan terhadap ukuran dan bentuk tubuh individu. Gangguan citra tubuh dapat dibagi dua, berdasarkan komponen citra tubuh yang terganggu yaitu body image dissatisfaction dan body image distortion. Masalah distorsi tubuh merupakan pencitraan atau penampilan seseorang terutama pada wanita yang dipengaruhi oleh faktor pengetahuan gizi, konsep diri, yaitu kepercayaan dan harga diri, aktivitas fisik, pengaruh keluarga dan teman serta media massa.
Hasil penelitian yang dilakukan pada 120 siswa SMAN 1 Pamulang Jakarta tahun 2009, citra tubuh yang dinilai dari perbandingan persepsi dengan status gizi yang sebenarnya menunjukan hasil 19,2\% siswa mengalami distorsi citra tubuh (Handayani, 2009). Penelitian Septiana dan Briawan (2010) pada 77 siswi dengan IMT > 22.9 di SMAN 1 Bogor tahun 2010, menunjukan bahwa $94.8 \%$ siswi memiliki persepsi tubuh negatif berdasarkan penilaian FRS dan $88.3 \%$ memiliki persepsi tubuh negatif berdasarkan penilaian BSQ. Selain itu, hasil penelitian ini menunjukkan bahwa faktor lingkungan yang paling besar berpengaruh pada persepsi tubuh seseorang adalah orang tua $(90.9 \%)$, teman (80.5\%), dan media massa $(68.8 \%)$.

Tujuan penelitian ini adalah untuk mengetahui persepsi bentuk ideal yang berlaku pada remaja putri, persepsi remaja terhadap bentuk tubuh yang dimiliki saat ini dan upaya yang dilakukan remaja untuk mencapai citra tubuh ideal.

\section{METODE PENELITIAN}

Penelitian ini menggunakan desain studi kualitatif dengan pendekatan fenomenologi. Pendekatan ini adalah metode yang tepat digunakan karena dapat menggali dan mengembangkan fenomena yang terjadi pada sekelompok individu dengan suatu pengalaman hidup yang khas. Metode ini amat berguna 
terutama ketika pribadi peneliti berpendirian bahwa nilai-nilai dan belief tertentu mungkin menetap di luar kesadarannya sehingga mengesampingkannya walaupun dengan menggunakan teknik-teknik reflektif formal.

Responden dalam penelitian ini adalah 6 orang siswi SMA Negeri 1 Bogor yang dipilih secara purposive sampling, dengan kriteria kurus BMI < 18,0 sebanyak 3 orang dan kriteria gemuk BMI > 25,0 juga sebanyak 3 orang.

Data tentang persepsi bentuk ideal yang berlaku pada remaja putri, persepsi remaja terhadap bentuk tubuh yang dimiliki saat ini dan upaya yang dilakukan remaja untuk mencapai citra tubuh ideal dikumpulkan dengan wawancara secara mendalam (indepth interview). Hasil wawancara dan diskusi perorangan ini dibuat dalam bentuk transkrip secara narasi, dan divalidasi kembali kepada responden untuk memberikan kepastian isi dengan jawaban yang diberikan responden. Data dianalisis melalui pendekatan kualitatif dengan menganalisis fenomenologi yang dapat digunakan untuk menganalisis data hasil wawancara peorangan secara mendalam. Setiap kalimat dalam transkrip dianalisis dan kode (yaitu, diberikan label untuk meringkas apa yang telah dikatakan), kemudian disatukan dalam tema-tema yang memiliki kemiripan.

\section{HASIL DAN PEMBAHASAN}

\section{A. Profil Responden}

Responden dalam penelitian ini adalah 6 (enam) orang siswi kelas dua SMA Negeri 1 Kota Bogor berusia antara 16-17 tahun dan duduk di kelas XI, 3 orang siswi dengan status gizi gemuk (IMT > 25,0) dan 3 orang lagi dengan status gizi kurus (IMT < 18,0). Sebagian besar responden memiliki latar belakang sosial ekonomi menengah ke atas dan bertempat tinggal di wilayah Kota Bogor, hanya 2 orang siswi yang bertempat tinggal di luar Kota Bogor, yaitu di daerah Ciawi dan Ciampea yang masuk dalam wilayah Kabupaten Bogor.

\section{B. Persepsi BentukTubuh Ideal}

Setiap orang memiliki persepsi bentuk tubuh ideal yang berbeda-beda, karena persepsi bentuk tubuh seseorang dibentuk dan dipengaruhi oleh berbagai faktor baik internal maupun eksternal. Beberapa penelitian menyatakan bahwa faktor eksternal yang mempengaruhi adalah lingkungan keluarga, teman sebaya dan tidak ketinggalan pengaruh dari media massa.

Hasil wawancara terhadap 3 orang siswi SMA Negeri 1 dengan kategori kurus (K1, K2, dan $\mathrm{K} 3$ ), tentang pemahaman bentuk atau citra tubuh ketiga responden ternyata mempunyai persepsi yang hampir sama, yaitu: 
"Bentuk tubuh ideal, penyimpangan lemak tidak terbagi rata dan seimbang antara tinggi dan berat badan"

Sedangkan hasil wawancara dengan topik yang sama terhadap 3 orang siswi SMA Negeri 1 dengan kategori gemuk. Bentuk tubuh atau citra tubuh ideal menurut mereka adalah:

"Setiap orang tidak sama, misalkan tipe Peer atau bulat pasir dll" (G1);

"Bentuk tubuh ideal adalah bentuk tubuh yang sesuai antara tinggi dan berat artinya proporsional, tidak ada yang berlebihan" (G2);

"Kata banyak orang tinggi badan dikurangi 110 dan secara visual gak terlalu kurus atau besar" (G3).

Pernyataan di atas mengindikasikan, hampir semua responden baik yang kurus maupun gemuk memiliki pemahaman yang sama tentang bentuk tubuh, yaitu keseimbangan antara berat badan dan tinggi badan. Hal ini menunjukkan bahwa mereka memiliki pemahaman yang baik tentang bentuk tubuh ideal dan didasarkan pada pengetahuan yang mereka peroleh dari pelajaran di sekolah. Hasil senada diperoleh Sri Adiningsih dalam penelitiannya pada siswa SMP di Surabaya yang menyatakan bahwa sebagian besar $(63,2 \%)$ remaja putri berpendapat tubuh idaman mereka adalah tinggi langsing dan 21,4\% menyatakan bentuk tubuh ideal adalah tinggi sepadan berat badan.
Bentuk tubuh ideal menurut responden pada umumnya baik yang kurus maupun gemuk adalah bentuk tubuh yang proporsional, alamiah, tinggi dan tidak terlalu gemuk maupun kurus. Pada umumnya mereka menjadikan artis tertentu sebagai gambaran seseorang yang memiliki bentuk tubuh ideal, hanya satu orang responden yang menyatakan tidak memiliki panutan. Hal ini tergambar dari pernyataan yang diberikan sebagai berikut :

K1: "Angelina Jolly, alami, tidak dibuat, kita tidak tahu atau tidak merusak diri sendiri"

K2: "Tidak ada panutan baik tokoh atau artis dan tidak mau ikutikutan karena artis sering tidak memiliki berat badan seimbang"

K3: "Dariartis Pevita Pearce karena bentuk tubuhnya proporsional"

G1: "Tergantung dari Tinggi seseorang. TB-110 hasilnya Berat Badan, contohnya Jenifer Lawrence artis holywood"

G2: "Publik figure karena mereka menjaga bentuk tubuhnya. Ratarata artis memiliki berat badan ideal."

G3: "Dari artis karena tinggi tapi tidak terlalu kurus"

Pernyataan responden tentang komponen atau bagian tubuh tertentu yang harus dimiliki sebagai kriteria bentuk tubuh ideal. Dua dari tiga responden dengan status gizi kurus menyatakan tidak ada bagian tubuh 
tertentu yang dianggap penting, dan hanya satu yang meyatakan bahwa:

"Lengan, kalau pakai baju bisa menutupi kekurangan, kemudian kaki yang lenjang, seimbang, tidak terlalu kurus"

Berbeda dengan responden yang gemuk, mereka berpendapat bahwa bagian tubuh tertentu yang harus dimiliki sebagai kriteria bentuk tubuh ideal adalah lengan, pinggang dan kaki, sesuai dengan pernyataan berikut :

G1 dan G3: "Menurut saya dari lebar tubuh, lengan, bentuk kaki yang tinggi dan kelihatan seimbang"

G2: "Komponen tubuh yang proporsional antara lingkar pinggang dan tubuh lainnya"

Maraknya sinetron remaja yang menampilkan artis cantik dan langsing serta penggunaan public figure atau model-model cantik, tinggi dan langsing dalam iklan-iklan di media massa memberikan pengaruh yang kuat dalam membentuk persepsi seseorang terutama remaja tentang bentuk tubuh ideal. Mereka akan merasa lebih percaya diri bila memiliki bentuk tubuh tinggi, langsing dan memiliki kaki jenjang seperti yang dimiliki artis pada sinetron ataupun iklan yang mereka tonton. Hal serupa diperoleh pada penelitian yang dilakukan Handayani (2009) di SMAN 1 Pamulang Jakarta, dimana proporsi remaja yang mengalami distorsi citra tubuh lebih banyak ditemukan pada kelompok remaja dengan pengaruh media massa yang besar yaitu sebesar $26.3 \%$. Penelitian Wong dan Say (2013) pada remaja di Malaysia didapatkan 25\% remaja putri menjadikan artis atau model sebagai panutan (role model), dan bila dilihat dari status gizinya, lebih banyak remaja yang memiliki status gizi kurang (underweight) menyatakan tidak memiliki panutan (44.8\%) dibandingkan mereka yang memiliki status gizi normal (33.7\%) dan gemuk (28.1\%).

Hasil yang menarik dalam penelitian ini adalah responden memiliki pandangan berbeda tentang persepsi tubuh ideal dengan persepsi yang dimiliki oleh keluarga atau teman di lingkungan sekolahnya. Senada dengan pendapat Mitola (2007) yang menyatakan bahwa kepuasan ukuran tubuh dilihat sebagai perbedaan antara bentuk tubuh ideal atau baik menurut remaja itu sendiri dengan bentuk tubuh ideal menurut lingkungannya terutama keluarga dan teman. Hal ini sesuai dengan ungkapan masing-masing responden yang mengemukakan:

K1: "Seperti teman saya pertumbuhannya pesat, wanita terdokrin oleh iklan, minum susu mengurangi berat badan, terima aja bentuk tubuh seperti itu"

K2: "Ada karena menurut teman dia kurus tapi menurut saya tidak" 
K3: "Persepsi teman sama tapi tidak tau persepsi dengan orang tua belum pernah diskusi"

Perbedaan persepsi antara responden dan lingkungan (teman/ keluarga) tentang tubuh ideal, juga disampaikan oleh responden dengan kategori gemuk yaitu :

G1: "Apa yang terlihat, kongkrit, proporsional. Banyak yang beranggapan yang kecil tapi $B B$ berlebihan"

G2: "Rata-rata menurut keluarga pendapat sama, tidak ada karena keluarga semuanya gemuk"

G3: "Menurut teman: mayoritas tinggi, putih dan tidak terlalu kurus dan terlalu gemuk, yang pas gitu , keluarga (kakak) : tinggi"

Pernyataan responden tersebut menggambarkan bahwa ada perbedaan persepsi bentuk tubuh ideal antara dirinya dengan keluarga atau teman di lingkungan sekolahnya. Keluarga terutama orangtua menginginkan bentuk tubuh ideal bagi anaknya adalah bentuk tubuh yang kurus. Hal ini juga ditemukan pada penelitian tahun 2011 di sekolah yang sama, yaitu sampel mengharapkan tubuh ideal pada gambar nomor 3, sedangkan keluarga dan teman teman mengharapkan sampel memiliki tubuh sesuai dengan gambar nomor 4 (Isnani, 2011).

\section{Persepsi bentuk tubuh saat ini}

Body image atau citra tubuh merupakan suatu konsep yang multi- dimensial, sehingga oleh beberapa ahli citra tubuh didefinisikan secara berbeda tergantung pada aspek dan bidang tertentu yang ditekuni. Menurut Grogan (2006), citra tubuh berhubungan dengan persepsi, perasaan dan pikiran seseorang tentang tubuhnya, biasanya digambarkan sebagai penggabungan ukuran tubuh, bentuk tubuh atau bagian tubuh yang menarik serta emosi atau perasaan yang terkait dengan bentuk tubuh. Citra tubuh dibentuk oleh persepsi, emosi, sensasi fisik, sehingga bersifat tidak statis, tetapi dapat berubah-ubah tergantung pada suasana hati, pengalaman fisik dan lingkungan yang ada.

Hasil penelitian menunjukkan bahwa responden umumnya merasakan bahwa bentuk tubuh yang dimiliki belum ideal karena tidak seimbang atau tidak proporsional. Hal ini tercermin dari jawaban responden yang bertubuh kurus:

"Belum ideal karena terlalu tinggi sehingga menjadi tidak seimbang dan terlihat seperti anak $S M P^{\prime \prime}(\mathrm{K} 1)$

"Secara visual merasa belum maksimal proporsional dan terlihat kurus"(K2 dan K3).

Sedangkan responden yang bertubuh gemuk menyatakan bahwa:

"Belum ideal dan merasa terlalu gemuk, tidak seimbang antara TB dan BB (G1, G2 dan G3).

Namun demikian 2 responden (G1 dan G2) menyatakan bahwa bentuk 
tubuh gemuk yang mereka miliki merupakan

"Factor keturunan, karena gen orang tua dan hampir seluruh anggota keluarga memiliki bentuk tubuh yang gemuk".

Persepsi tubuh negatif dalam penelitian ini, juga terlihat dari hampir sebagian besar contoh $(76.3 \%)$ pada penelitian Isnani di sekolah yang sama tahun 2011, mereka umumnya merasa memiliki bentuk tubuh yang tidak sesuai harapan, merasa tidak puas terhadap bentuk tubuhnya saat ini dan menginginkan bentuk tubuh yang lebih kurus, serta lebih tinggi dari tubuhnya saat ini. Hal senada ditemukan pada penelitian Kusumajaya dkk (2008) pada anak Sekolah Menengah Atas di Denpasar Bali, menunjukkan hasil yang sama, hanya $15,1 \%$ sampel yang menginginkan bentuk dan berat badan seperti keadaan mereka saat ini, sisanya sebanyak $47,9 \%$ menginginkan lebih kurus dan sebanyak 37,0\% justru ingin menambah berat badannya.

Dua dari tiga responden dengan kategori kurus, menyatakan bahwa bagian tubuh yang belum ideal, adalah bagian tangan dan kaki, seperti pernyataan dari :

K1 dan K3: "Tangan yang terlalu kecil, kaki kurang tinggi atau jenjang"

Sedangkan K2 menyatakan bahwa semua bagian tubuh harus seimbang. Sedangkan responden yang gemuk memiliki pendapat yang berbeda terhadap bagian tubuh yang belum ideal, yaitu:

"Pinggul ke bawah" (G1);

"Semuanya karena tidak proporsional" (G2);

"Bagian kaki dan tangan, kata orang tangan dan kaki saya kurang panjang" (G3).

Bagian tubuh yang belum ideal menurut pendapat responden di atas hampir sama dengan hasil penelitian Widianti dan Candra (2012) pada remaja putri di SMA Theresiana Semarang, menyatakan bahwa $40.3 \%$ remaja perempuan merasakan ketidakpuasan terhadap bentuk tubuhnya, khususnya pada bagian kaki, pinggul, pantat, perut dan paha.

Terdapat penilaian bentuk tubuh yang berbeda antara keluarga dan teman pada remaja yang kurus. Lingkungan keluarga terutama orang tua menilai bentuk tubuh yang dimiliki responden saat ini sudah cukup ideal seperti yang disampaikan oleh

K2: "Menurutkeluargasudah pantas mempunyai berat badan seperti yang dimiliki sekarang"

Bahkan berlebih, seperti yang disampaikan oleh

K3: "Menurutorang tua (ibu) sudah termasuk gendut karena berat badan saya naik dari $39-42 \mathrm{~kg}$, padahal jaman ibu saya dulu berat badannya tidak lebih dari 40 kg." 
Sedangkan teman maupun guru di sekolah memberikan penilaian bentuk tubuh remaja tersebut masih termasuk dalam kategori kurus atau pendek, sesuai dengan ungkapan responden

K1: "Kamu kurus banget kata guru, teman-teman anggap kecil, suruh makan banyak, perubahan belum signifikan"

K3: "Menurut teman bentuk tubuh saya pendek, padahal belum tentu pendek bisa saja ideal.

Kecenderungan yang sama ditemukan pada responden yang gemuk, Keluarga menilai bentuk tubuh responden yang tidak terlalu gemuk bila dibandingkan dengan anggota keluarga lain, karena ternyata 2 dari 3 responden pada kelompok ini, berasal dari keluarga yang sebagian besar berstatus gizi lebih juga. Hal ini terungkap dari pernyataan

G1: “Tanggapan keluarga: tidak terlalu besar diantara keluarga saya".

G2: "Biasa saja karena dalam keluarga semuanya gemuk"

G3: "Menurut saudara bentuk tubuh saya tinggi karena mayoritas di keluarga rata-rata 160 an tapi saya $168 \mathrm{~cm}$. Menurut orang tua (ibu) kaki kurang panjang".

Penilaian berbeda diberikan oleh teman, yang sebagian besar menyatakan bahwa responden memiliki tubuh yang gemuk.
Pernyataan di atas, memperlihatkan bahwa pengaruh teman terhadap persepsi bentuk tubuh ideal lebih dominan dibandingkan keluarga. Hal ini berbeda dengan penelitian Dewi di SMA yang sama tahun 2010 serta penelitian Septiadewi dan Briawan (2010) menyatakan bahwa faktor lingkungan terutama orangtua memiliki pengaruh yang paling besar pada persepsi tubuh remaja. Hasil penelitian Musaiger pada remaja di Dubai didapatkan bahwa seiring peningkatan berat badan remaja, tekanan untuk menurunkan berat badan dari orang tua juga semakin meningkat. Pada remaja putri yang mengalami kelebihan berat badan, 31.8\% dipaksa oleh orang tua untuk menurunkan berat badannya, dan proporsi ini meningkat menjadi $53.6 \%$ pada remaja perempuan yang gemuk.

\section{Upaya Pencapaian Bentuk Tubuh Ideal}

Hasil wawancara secara mendalam, terungkap bahwa untuk mencapai bentuk tubuh ideal pada responden yang bertubuh kurus dilakukan dengan menambah asupan makanan dalam bentuk susu atau suplemen vitamin serta berolahraga, seperti yang disampaikan oleh:

K1: "Minum susu nambah asupan gizi, bangun tidur minum air putih, makan teratur, orang sibuk di sekolah melewatkan waktu makan 
K2: "Saya hanya minum vitamin, menambah jumlah makanan dan berolah raga"

K3: "Saya lakukan olah raga dan menari"

Sedangkan pada responden yang gemuk dilakukan dengan menjalani diet dibawah pengawasan dokter dan ahli gizi serta berolah raga. Pernyataan responden dengan status gizi gemuk adalah sebagai berikut:

G1: "Pernah ke Dokter Ahli Gizi dikasih resep makan sehari-hari untuk menurunkan berat badan, kemudia berhenti karena dokter kurang cocok"

G2: "Diet mulai SMP dibawah pengawasan dokter, upaya lain tidak makan malam hari"

G3: "Olahraga basket dan berenang"

Hasil penelitian ini mendukung penelitian sebelumnya yang dilakukan oleh Widianti dan Candra (2012) yang menunjukkan bahwa pada kelompok subyek dengan status gizi lebih melakukan berbagai cara untuk menurunkan berat badannya antara lain mengurangi porsi makan, melakukan olahraga dan bahkan ada yang mengkonsumsi obat pelangsing. Dalam satu bulan terakhir, didapatkan $66.2 \%$ remaja perempuan di SMAN 1 Kota Bogor, melakukan upaya pencapaian citra tubuh ideal, jenis upaya yang dilakukan yaitu $23.4 \%$ melalui penggabungan antara makanan dan olahraga serta $22.1 \%$ melalui olahraga saja. Namun demikian, masih ditemukan $36.4 \%$ remaja yang melakukan upaya pencapaian citra tubuh ideal melalui cara yang tidak sehat yaitu dengan melewatkan waktu makan $(29.9 \%)$, sisanya melalui tidak makan karbohidrat sama sekali, bulimia dan konsumsi obat pencahar (Septiana dan Briawan, 2010).

Walaupun berbeda dalam penyampaiannya, umumnya responden berpendapat bahwa pembatasan makan yang dilakukan seseorang untuk menjaga bentuk tubuhnya merupakan sesuatu hal yang wajar bila tidak berlebihan dan harus diimbangi dengan konsumsi makanan sehat lainnya seperti sayur dan buah atau dengan banyak melakukan aktivitas fisik. Berikut adalah pernyataan yang disampaikan oleh responden:

"Kalau masih seimbang gak perlu, kecuali mereka yang gendut karena bahaya bisa menimbulkan penyakit, diet yang dilakukan haruslah diet yang sehat, yaitu dengan banyak makan sayur dan buah atau dengan lebih banyak melakukan aktivitas olahraga"

Hasil penelitian menunjukkan bahwa responden tidak setuju dengan upaya seseorang yang mencoba mengosongkan lambungnya untuk menjaga bentuk tubuh yang ideal merupakan suatu hal yang salah dan dapat menyakiti diri sendiri, sesuai dengan pernyataan berikut: 
K2: "Belum melihat hanya mendengar, itu tidak baik karena seperti tidak bersyukur dan mubazir"

K1, K3, G1 dan G3: "Tidak setuju dan perbuatan salah, karena dapat menyakiti atau menyiksa diri sendiri"

G2: "Mengosongkan lambung seperti artis luarnegeri seperti anoreksia, itu tidak baik karena dapat menyakiti diri sendiri"

Hal ini sejalan dengan penelitian Isnani yang menyatakan bahwa semua sampel berpendapat bahwa upaya pencapaian bentuk tubuh ideal harus dilakukan dengan upaya yang benar, dengan tidak melakukan tindakan yang salah dan dapat menimbulkan dampak terhadap kesehatan seperti meminum obat pencuci perut, obat pelangsing, atau memintahkan makanan yang sudah dimakan (bulimia).

Kebiasaan melewatkan waktu makan baik makan pagi, siang ataupun malam ditemukan pada sebagian besar remaja dalam penelitian ini, dapat dilihat dari jawaban remaja dengan status gizi kurus tentang kebiasaan tidak makan disaat waktu makan sebagai berikut:

K1: "Kalau dulu makan teratur tapi sekarang sering melewatkan waktu makan, hanya makan roti dan malam tidak makan"

K2: "Sering membiasakan terutama siang dan pagi. Siang: lagi urusan apa, perut udah lapar, makan urusan nanti. Pagi: Tidak biasa sarapan pagi, di keluarga juga"

K3: "Sering terutama makan pagi karena tidak sempat, cuma sarapan air putih dan susu serta kadang membawa bekal ke sekolah (3 kali seminggu). Siang makan nasi bareng teman di sekolah. Malam makan nasi sama keluarga, tetapi kalau pulang les merasa capek tidak makan malam "

Sedangkan responden dengan status gizi lebih memberikan pernyataan sebagai berikut :

G1: "Makan kalau ingat saja, yang pasti makan pagi, siang jarang makan di sekolah jarang makan malam"

Jawaban yang sedikit berbeda didapatkan dari 2 responden gemuk lainnya, dimana kebiasaan melewatkan waktu makan pernah dilakukan sebelumnya, namun saat ini sudah tidak dilakukan lagi akibat rasa sakit yang ditimbulkan oleh tindakan tersebut.

G2: "Tidak, sebelumnya waktu SMP telat 30 menit tapi sekarang teratur"

G3: "Pernah melewatkan waktu makan karena kepingin kurus tapi menjadi sakit maag dan sekarang tidak mau lagi"

Demikian halnya dengan kebiasaan mengurangi porsi makan sebagian besar dilakukan oleh res- 
ponden walaupun status gizi mereka masuk dalam kategori kurus, berikut pernyataan 5 dari 6 responden :

"Hasrat saya untuk makan pagi kurang, makan nasi tidak banyak, jam 8 ngemil lagi, siang dan malam teratur"

"Porsi yang saya makan menurut saya cukup tapi kata orang tua saya masih kurang, porsi makan saya lebih sedikit dibandingkan adik perempuan saya yang masih kelas 6 SD"

"Biasa mengurangi porsi Nasi (6 sendok makan yang dimakan/ditakar) biasa ada ayam dan tempe, pilih salah satu kemudian ditambah sayur"

"Iya, makan sedikit dan ditakar, pagi sarapan roti, makan siang sedikit, makan malam buah"

"Biasa saja, tidak suka makan dari kecil, karena saya gemuk dari keturunan. Kalau saya lebih memilih makan sayur dan buah"

Hanya responden $\mathrm{K} 1$ yang menyatakan "Tidak pernah mengurangi porsi makan"

Gambaran kebiasaan melewatkan waktu makan atau mengurangi porsi makanan pada penelitian ini sesuai dengan penelitian Freeland dalam Chairiah (2012) yang menyatakan bahwa akibat kesibukan yang dihadapi remaja saat ini membuat mereka cenderung hanya memakan makanan yang tersedia atau makanan yang dengan cepat dan mudah mereka dapatkan. Bila pada waktu makan, tidak tersedia makanan, maka remaja lebih sering melewatkan saja waktu makan tersebut, hal ini terutama terjadi pada waktu sarapan. Hal ini jelas dapat mengurangi jumlah porsi makanan maupun zat gizi yang dikonsumsi sehari-hari.

Hasil penelitian Cheung, et al (2007) pada pelajar secondary school di Hong Kong menunjukkan bahwa keinginan untuk menurunkan berat badan lebih banyak ditemukan pada remaja yang gemuk daripada remaja yang memiliki berat badan normal (58,6\% dan 40,7\%) dan pembatasan makanan dilakukan oleh 52.3\%-68.4\% responden. Program pembatasan makanan juga dilakukan oleh 51.7\% sampai $70.5 \%$ remaja yang kelebihan berat badan pada sekolah pemerintah di Dubai dan proporsi ini semakin meningkat pada remaja yang gemuk menjadi 63.9\% sampai 68.1\% (Musaiger et al, 2012).

Olahraga atau aktivitas fisik lainnya diluar jam pelajaran sekolah merupakan upaya yang paling banyak dilakukan oleh remaja baik yang kurus maupun gemuk untuk mendapatkan bentuk tubuh ideal. Jenis olahraga yang dilakukan bervariasi, meliputi renang, bulutangkis, basket, bela diri dan ada pula olahraga berupa latihan menari. Umumnya kegiatan tersebut dilakukan secara rutin antara 1 sampai 2 kali per minggu Hanya satu responden yang menyatakan jarang melakukan olahraga dikarenakan kesibukan di sekolah.

Responden termotivasi melakukan olahraga/aktivitas fisik karena berbagai alasan, yaitu: 
K1: "M emang sudah kebiasaan keluarga, ayah main bulu tangkis, renang karena dari kecil"

K2, K3 dan G1: "Supaya sehat, tubuh tetap fit dan membentuk tubuh"

G2: "Disarankan oleh dokter untuk olah raga"

G3: "Lebih enak di badan, karena kalau di sekolah padat dengan belajar jadi kurang aktivitas"

Berdasarkan hasil penelitian Isnani (2011), di SMAN 1 Bogor, jenis olahraga yang paling banyak dilakukan menurut contoh berstatus gizi kurus dan normal untuk pencapaian tubuh ideal adalah jogging (67.5\%), lari $(62.5 \%)$, renang $(47.5 \%)$.

Selain berolahraga, beberapa responden juga pernah menggunakan obat-obatan tertentu untuk mendapatkan bentuk tubuh ideal, namun sejauh ini obat-obatan yang digunakan termasuk dalam kategori yang aman untuk kesehatan berupa vitamin atau obat herbal dan tradisional lainnya.

Sebagian besar responden dalam penelitian ini mendapatkan informasi tentang khasiat obat dalam membentuk tubuh ideal dari keluarga sedangkan sisanya memperoleh informasi melalui internet, iklan televisi atau dokter, seperti pernyataan berikut :

"Dari saudara, buat stamina aja tidak gemukin badan. Minum susu sebelum menikah, terapi listrik, akupuntur"
"Dari keluarga dan disediakan oleh ibu dan internet supaya tidak terlalu capek minum vitamin."

"Iklan televisi katanya dapat menambah tinggi badan, tapi hasilnya tidak kerasa."

"Kalau tahu sih tahu, kenapa tidak secara alami aja kenapa pakai obat. Obat ada bahan kimianya. Kalau alami lebih terjamin aman"

"Dari dokter yang menangani diet dan keluarga"

"Dari keluarga terutama kakak saya"

\section{KESIMPULAN}

Bentuk atau citra tubuh yang diinginkan oleh remaja putri di SMAN 1 Kota Bogor baik yang kurus dan gemuk adalah keseimbangan antara tinggi dan berat badan, serta bentuk tubuh tinggi dan langsing seperti yang digambarkan oleh artis atau public figure yang sering mereka lihat pada sinetron atau iklan di media terutama televisi.

Sebagian besar responden menyatakan ketidakpuasannya terhadap bentuk tubuhnya saat ini atau bagianbagian tubuh tertentu seperti kaki dan pinggul yang belum sesuai keinginan. Hal ini akibat pendapat atau pengaruh teman di sekolah maupun keluarga di rumah.

Kesibukan di sekolah seringkali mengakibatkan remaja melewatkan waktu makan atau hanya memakan makanan yang tersedia dengan jumlah yang tidak mencukupi kebutuhannya. Namun mereka menyatakan bahwa meminum obat pencuci perut, obat 
pelangsing, atau memuntahkan makanan yang sudah dimakan merupakan tindakan yang salah dan dapat menimbulkan dampak terhadap kesehatan. Mereka lebih memilih melakukan aktivitas fisik dan berolahraga serta mengkonsumsi vitamin untuk mencapai bentuk tubuh ideal.

Pengaruh lingkungan baik keluarga, teman maupun media massa sangat menentukan persepsi citra tubuh seorang remaja, oleh karena itu peran keluarga dan sekolah sangatlah penting. Keluarga terutama ibu perlu memantau pertumbuhan dan perkembangan anaknya sedangkan pihak sekolah perlu menanamkan konsep citra diri yang benar melalui penyuluhan atau konseling sehingga dapat memberikan persepsi dan tindakan yang benar bagi remaja terutama mereka yang mengalami distorsi citra tubuh.

\section{DAFTAR PUSTAKA}

Cash, T. 2002. Cognitive-Behavioral Perspectives on Body Image, in Cash and Pruzinsky. Body Image A Handbook of Theory, Research, and Clinical Practice. New York : The Guilford Press.

Cheung, P.C.H., Patricia, L.S Ip, Lam, S.T and Bibby, H. 2007. A Study on Body Weight Perception and ht Control Behaviours among Adolescent in Hong Kong. Hong Kong Med Journal, 13(1): 16-21

Chairiah, P. 2012. Hubungan Gambaran Body Image dan Pola Makan Remaja Putri di SMAN 38 Jakarta. Skripsi Fakultas Ilmu Keperawatan UI

Grogan, S. 2006.Body Image andHealth: Contemporary Perspectives. Journal of Health, 11(4): 523-530

Isnani, F. 2011. Praktik Hidup Sehat dan Persepsi Tubuh Ideal Remaja Putri SMA Negeri 1 Kota Bogor. Skripsi Fakultas Ekologi Manusia IPB

Handayani, M. 2009. Faktor-Faktor yang Mempengaruhi Distorsi Citra Tubuh Siswa SMAN I Pamulang Tahun 2009. Skripsi Fakultas Kedokteran dan Ilmu Kesehatan UIN Syarief Hidayatullah

Kusumajaya, N.A.A., Wiardami, N.K. dan Juniarsama, I.W., 2008. Persepsi Remaja terhadap Body Image (Citra Tubuh) Kaitannya dengan Pola Konsumsi Makan dan Status Gizi. Jurnal Skala Husada, 5(2) : 114-125

Mitola, A.L., Papas, M.A., Le, K., Fusillo, L, and Black, M.M., 2007. Agreement with Satisfaction in Adolescent Body Size between Female Caregivers and Teens 
from a Low income African American Community. Journal of Paediatric Psychology, $32: 42-51$

Musaiger, A.O., bin Zaal, A.A, and D'Souza, R., 2012. Body weight perception among adolescents in Dubai, United Arab Emirates. Nutricion Hospitalaria, 27(6):19661972

Septiana dan Briawan. 2010. Penggunaan Metode Body Shape Questionnaire (BSQ) dan Figure Rating Scale (FRS) untuk Pengukuran Persepsi Tubuh Remaja Perempuan. Gizi Indonesia, 33(1): 29-36

Widianti dan Candra. 2012. Hubungan antara Body Image dan Perilaku Makan dengan Status Gizi Remaja Putri di SMA Theresiana Semarang. Journal of Nutrition Collegem 1(1): 244-255

Wong and Say. 2012. Gender Differences in Body Image Perception among Northern Malaysian Tertiary Students. British Journal of Medicine E Medical Research, 3(3): 727-747

Zoletic and Belko. 2009. Body Image Distortion, Perfectionism and Eating Disorder Symptoms in Risk Group of Female Ballet Dancers and Models and in Control Group of Female Students. Psychiatria Danubina, 21(3): 302-309. 